\title{
On 'Grundtvig's eschatology and its realistic significance: A Chinese view' - a prefatory commentary
}

\author{
By A. M. Allchin
}

During the second half of the twentieth century, the study of Grundtvig and the subsequent influence of his ideas has been gradually spreading beyond the Western European and North American world. In the Philippines for instance the work of Edicio de la Torre has helped to make Grundtvig's whole life and work known and come to life in a new situation: "Light - life - and yes - hope" is his motto.

In West Africa the enthusiasm of Dr Kachi Ozumba has made the educational ideas of Grundtvig known in another way in $\mathrm{Oba}$ in Nigeria. Perhaps most striking of all in recent years has been the work of Dr Asoke Bhattacharya at the Centre for Adult and Continuing Education at Jadavpur University, Kolkata, where the new development of the Centre's work has taken up and renewed the inspiration which first came to Bengal from the work of Rabindranath Tagore in the first years of the twentieth century. The Grundtvig initiative has now been transferred to Satyen Maitra Janasiksha Samity and the Grundtvig India Society for Popular Enlightenment and Human Development.

One of the things which these and other experiments in transplanting Grundtvig's ideas from one world to another have in common is the way in which they all take up Grundtvig's particular concerns of the $1830 \mathrm{~s}$ and $40 \mathrm{~s}$. This was a time when he became more and more involved in the work of popular adult education, seeking to raise the level of knowledge and understanding in the villages and country towns of Denmark, so that the whole Danish people might be more ready to take their part in the new life, political and cultural, of their nation, which was then developing. To look back on these and similar movements towards an international awareness of Grundtvig's ideas is perhaps particularly valuable here, because in this current number of Grundtvig Studies we have an altogether new and different presentation of Grundtvig's teachings, coming to us from the Far East. Here, in the article by Wen Ge, we are seeing Grundtvig's theology as it has been received and welcomed in recent years in an altogether new way, in the largest nation on our planet. This particular Chinese presentation of Grundtvig's thought reveals an inner consistency and balance which seeks to penetrate to the very heart of his work as a theologian, expounding the realistic significance of his eschatology. 
Indeed in this work we find an exposition not only of Grundtvig's eschatology but also of his understanding of the doctrine of the Trinity as being at the heart of Christian faith and life. This remarkable presentation of Grundtvig's theological vision on the part of a young and as yet little known Chinese scholar commands our careful attention and our deep gratitude. If the writer at times has difficulties with the full expression of his thoughts in the English language, there can be no question about the depth and seriousness of his presentation of the subject. It is a presentation of Grundtvig's Christian faith as we find it alike in his hymns, his sermons and his theological treatises. Here, from a quarter where we had hardly expected it, we have a new and all-encompassing picture of his work.

One of the basic things which the writer makes us aware of, both at the beginning and the end of his work, is that, for large parts of the Protestant world in China, this positive eschatological vision which the essay presents is something very largely new. It seems that a kind of pietistic presentation of the nature of Christian faith in general, individualist and with little or no vision of the wholeness of Christian understanding of God's purposes for his world has marked large areas of Chinese Protestantism:

Chinese Christians $[\ldots]$ have been concerned only with the redemption of individual spiritual life. They have held an inactive and pessimistic attitude to an involvement in social affairs for they believe that on the day of judgment everything in this world will be destroyed.

In this context, the writer insists, Grundtvig's view of the Christian faith "can offer some wonderful new insights into these aspects of our faith".

The writer begins by setting out his aims: "to discuss the realistic significance of Grundtvig's eschatology." $\mathrm{He}$ goes on to describe different aspects of the social and intellectual background of the nineteenth century against which Grundtvig worked. He then comes to the basic sources from which his eschatological vision was developed, the Scriptures of the Church and the early Fathers. He sketches out the contents of this eschatology which again he summarises under three headings: "first the meaning of Jesus' resurrection, then communion with the Triune God and third theosis through faith hope and love." $\mathrm{He}$ concludes: "finally I will try to reflect on the realistic significance of this view from the perspective of a Chinese Protestant Christian."

Wen Ge goes on:

Serious theological thinking with the clear purpose of serving the Church is not something which can be done in an ivory tower, it needs to be correlated with its social and intellectual context. Grundtvig is a great Church theologian whose theology is embodied primarily in his 
sermons, his hymns and his liturgical texts. So in his eschatology he does not fight like one beating the air, but he addresses the concrete challenges of his own lifetime.

How Wen Ge himself tackles the discussion of these questions can be seen in the following pages of his article, starting from the early influence of the philosophy of Schelling and then going on to see how, without altogether repudiating the "romanticism of those early years", Grundtvig never lost his deep concern for "the study of history, mythology and poetry". Indeed, we might say that the three areas remained of fundamental importance to him, as himself an outstanding historian, poet and mythologist throughout the whole of his life.

But Wen Ge's discussion of the universal human and cultural background to an understanding of the specifically Christian character of the New Testament sources of Christian faith leads him on to an understanding of Grundtvig's inclusive eschatology, which argues "that adherents of other tradition may relate savingly to God" but without losing the uniqueness of Christianity at the same time. "In hindsight, Grundtvig's efforts here can be regarded as a good example of doing contextual theology in such a way that a positive synthesis comes into being without disregarding Christian identity."

Not surprisingly it is to the fourth Gospel that Grundtvig turns above all when he comes to the study of the New Testament. Nor need we be surprised when we find that Wen Ge in his understanding of that Gospel turns to the commentaries of C. H. Dodd with their detailed working out of the realized eschatology of this central New Testament text.

Wen Ge however goes on further into the tradition of the early Church by setting out in some detail Grundtvig's understanding of the great second-century theologian Irenaeus. It is interesting to note here that Wen Ge quotes lines from Paul Tillich to underline the doctrine of anakephalaiosis, the summing up of all things in Christ which we find in Irenaeus. Here as in other places Wen Ge chooses his theological authorities with some care, though one suspects that the resources of the libraries available to him are somewhat limited in this respect.

Having turned to the fourth Gospel and the theology of Irenaeus for the foundation of Wen Ge's own eschatological view we come now to his understanding of the contents of that eschatology and here it is interesting to find that he turns to the contemporary Anglican theologian Alistair McGrath. For him there are three crucial aspects of this doctrine: first the meaning of Jesus' resurrection, then the coming of the kingdom of God and third the ultimate destiny of the creation. It is thus that Grundtvig can 
see Easter as both a cosmic and corporate reality involving the whole believing human race, and thus see it as the end and fulfilment of human history, nothing less than a fusion together of human and divine, a fusion together of heaven and earth in the love which the indwelling Spirit brings.

Again Wen Ge points us towards the negative nature of some at least of Chinese Protestant theology and its failure to relate in any way positively with the vision of traditional Chinese culture and religion. Here, he suggests, there is a particular potential in the thought and in the poetry of Grundtvig. For Grundtvig the resurrection involves the descent into hell and the destruction of death by death; and in the communion of saints, the Ancestors for whom Chinese traditional religion has so much respect are certainly not forgotten, indeed they are raised with Christ.

Again Wen Ge refers to the topics being discussed at the present time in China, in the movement of Theological Thinking Reconstruction, and again he suggests that there are unexpected resources to be found in the theology of Grundtvig both in prose and in verse.

Then, almost at the end of his whole presentation, the writer pauses and asks whether this kind of realized eschatology can really respond to the darkness of our times, the time of Auschwitz and Hiroshima and of other more recent manifestations of humanity's fallen condition. Unexpectedly Wen Ge continues

with this challenge, I do not think realized eschatology can hold water. Instead, the inaugurated eschatology is more persuasive. Besides, maybe more room should be left for God's transcendence in his system, so that the realization of eschatology will not go so much along the humanistic line.

However, this unexpected but highly significant qualification of the general trend of Wen Ge's argument is not the end of his exposition. For that we must surely allow him to speak for himself.

All in all Grundtvig is a theologian who is deeply concerned about the existence and meaning of the Church in the world. It is from the perspective of the Church that his eschatology provides a new vision of God's kingdom in the realistic sense. However, the fullness of God's mystery is never grasped by us. It is hidden in the Father who is the Source, it overflows in Christ, beyond the measure of our means to receive it, and it is continuously active in all of creation through the Spirit. From this, we may understand why Grundtvig's eschatology should end with doxology, full of hope and joy. 